REA D I NG A U D E N 



\section{READING AUDEN}

\section{THE RETURNS OF CALIBAN}

J O H N R. B O L Y

CORNELL UNIVERSITY PRESS

ITHACA AND LONDON 
Copyright $@ 1991$ by Cornell University

All rights reserved. Except for brief quotations in a review, this book, or parts thereof, must not be reproduced in any form without permission in writing from the publisher. For information, address Cornell University Press, 124 Roberts Place, Ithaca, New York 14850.

First published 1991 by Cornell University Press.

Excerpts from W. H. Auden: Collected Poems, edited by Edward Mendelson, copyright $(\subset) 1976$ by Edward Mendelson, William Meredith, and Monroe K. Spears; Tbe Dyer's Hand and Otber Essays, copyright () 1962 by W. H. Auden; and The Englisb Auden, edited by Edward Mendelson, copyright $\odot 1977$ by Edward Mendelson, William Meredith, and Monroe K. Spears reprinted by permission of Faber and Faber Ltd, and Random House, Inc.

Excerpt from Selected Poems by W. H. Auden reprinted by permission of Random House, Inc. Excerpts from The Encbafed Flood by W. H. Auden reprinted by permission of the University Press of Virginia.

International Standard Book Number 0-8014-2565-4

Library of Congress Catalog Card Number 91-6948

Librarians: Library of Congress cataloging information appears on tbe last page of the book.

(2) The paper in this book meets the minimum requirements of the American National Standard for Information SciencesPermanence of Paper for Printed Library Materials, ANSI Z39.48-1984. 
FOR LINDA AND CARIMORE ACUTE AUDITORS 
